\title{
The Effect of the Medium and the Variety on the Yield of Shallots (Allium ascalonicum L.) Grown in a Polybag
}

\author{
Nini Marta ${ }^{1 *}$, Kuswandi ${ }^{1}$, Mega Andini ${ }^{1}$, Sunyoto ${ }^{1}$, Yulia Irawati ${ }^{1}$, Nofiarli ${ }^{1}$, Fitriana Nasution $^{1}$ \\ ${ }^{1}$ Indonesian Tropical Fruit Research Institute \\ Jl. Raya Solok Aripan Km.8, West Sumatra, Indonesia \\ *Corresponding author: nasution79@gmail.com
}

\section{ARTICLE HISTORY}

Received : 8 January 2020

Revised : 23 March 2020

Accepted : 16 April 2020

\section{KEYWORDS}

Shallot;

Variety;

Medium;

Yield;

Bulb;

\begin{abstract}
Shallot is an important spice and seasoning in Indonesia. It is consumed almost daily in many dishes. The objective of this experiment was to study the effect of the medium and the variety on the yield of shallots grown in a polybag. The experiments were arranged in a two-factorial randomized complete block design with three replications. The factors were medium (1 soil: 1 paddy husk ash and 1 soil: 1 compost) and variety (Agrihorti 1 and Mentes). Data were statistically analyzed by Analysis of Variance (ANOVA), and the means were compared using Honestly Significant Difference (HSD) at $\mathrm{P}<0.05$. There was no interaction between medium and variety. Overall, all treatments did not significantly affect yield. Varieties were significant differences on bulb diameter; however, they were not significant differences on bulb height, fresh bulb weight per polybag, and bulb number per polybag. Those media are considered as precise media due to they contain organic materials.
\end{abstract}

This is an open-access article under the CC-BY-SA license.

\section{INTRODUCTION}

Shallot (Allium ascalonicum L.) is an important spice and seasoning in Indonesia. Alliums are essential vegetables and consumed almost daily in many dishes (Sulistyaningsih, et al., 2002; Yitagesu-Kuma, et al., 2015). This commodity is commonly used as a condiment in Southeast Asian countries, including Indonesia (Ariyanti, et al., 2018). In Africa, especially Ethiopia, this crop is used for traditional dishes (Getahun, 2016). Shallot is a proper food for a healthy diet because it has high concentrations of quercetin, isorhamnetin, and glycosides (Fattorusso, et al., 2002). It has an important ingredient for human health because it exhibits antioxidant (Liang, et al., 2012), anticarcinogenic and anti-inflammatory (Mohammadi-Motlagh, et al., 2011; Moradi, et al., 2013).

Soil mixtures or medium is an important factor for the performance of the plant in a polybag (C. A, et al., 2014). Using polybags to grow plants has some advantages, i.e., farmers can select healthy seedlings and vigorous plants (Adu-Yeboah, et al., 2015). Shallot has sharp price fluctuation (Susanawati, et al., 2015), thus planting this crop in a polybag is a solution for small society. Vegetable cultivation technique in polybags or pots as diversification and efficient land use in nature (Suthamathy \& Seran, 2011).
Shallot has sparse root hairs, shallow roots and these roots are not efficient to uptake the nutrients (Priyadharsini, et al., 2012). Therefore, it is necessary to find the appropriate medium to increase shallot yield. Shallot requires a constant of soil moisture (Woldetsadik, 2003). Some experiments to increase the production of shallot use media, which consisted of vermicompost, organic fertilizer, and microorganism, were examined by some researchers (Tambunan, et al., 2014; Anisyah, et al., 2014; Mahdalena, et al., 2016).

Using the appropriate variety is an effort to support the production of crops. This research used two varieties (Agrihorti I and Mentes), which collected from Vegetable Crop Institute, Lembang, Indonesia. Agrihorti I able to adapt at the dry season, and Mentes is suitable to grow in the lowland. Mentes and Agrihort I was released by Vegetable Crop Institute, Indonesian Agency for Agricultural Development (IAARD), in 2011 and 2015.

The objective of this experiment was to study the effect of the medium and the variety on the yield of shallots grown in a polybag.

\section{MATERIALS AND METHODS}

The research was conducted at the Indonesian Tropical Fruit Research Institute (ITFRI), Solok, West Sumatra, 
from March to June 2017. Shallot bulbs were planted in a polybag $\left(30 \times 40 \mathrm{~cm}^{2}\right)$, each polybag was planted with one bulb. The experiment was arranged in a two-factorial Randomized Complete Block design with two factors and three replications. The first factor was medium with two levels, soil:paddy husk ash (1:1), and soil:compost (1:1), the second factor was variety, Agrihorti 1 and Mentes. The treatment was a combination of both factors, and every treatment consisted of 15 polybags.

The compost was obtained by mixing cattle manure, sawdust, dolomite $\left(\mathrm{CaMg}\left(\mathrm{CO}_{3}\right)_{2}\right.$, Mexican sunflower (Tithonia diversifolia), paddy husk ash, and Trichoderma. Parameters were bulb diameter, bulb height, fresh bulb weight per polybag, and bulb number per polybag. Data of fresh bulbs were recorded at the end of the study. Plants were irrigated as when necessary during the duration of the experiment.

Data were statistically analyzed using Analysis of Variance (ANOVA), and means were compared using Honestly Significant Difference (HSD) at $\mathrm{P}<0.05$.

\section{RESULTS AND DISCUSSIONS}

Bulb yield was not statistically different $(\mathrm{P}<0.05)$ by the treatments, and there were no interaction between medium and variety (Table 1). These media (M1 and M2) had a similar effect on the yield parameter of shallot. Compost contains $90-95 \%$ of organic content as a soil conditioner (Khater, 2015).

The results showed that both media gave a positive effect on yield because the production of shallot in media was 74.94 to 79.20 gram/cluster. These media content organic matter, and in fact, this result was not different to experiment by Purba (2014) that used synthetic fertilizer, it produced 73.28 gram/cluster. The result of this study is similar to Santosa (2015) found that bulbs yield were 70.4-114.3 gram/hill in the soil, which applied to inorganic and organic fertilizer. It can be concluded that organic material can replace synthetic fertilizer.

In this study, the bulb's diameter in different media was $2.40 \mathrm{~cm}$ and $2.47 \mathrm{~cm}$. Kemal (2013) stated that bulb diameter was influenced by media, which high $\mathrm{N}$ contains and irrigation.

Table 1. Yield Parameters of Shallots in a Polybag

\begin{tabular}{|c|c|c|c|c|}
\hline Treatments & $\begin{array}{l}\text { Bulb diameter } \\
\qquad(\mathrm{cm})\end{array}$ & $\begin{array}{l}\text { Bulb height } \\
\qquad(\mathrm{cm})\end{array}$ & $\begin{array}{l}\text { Fresh bulb weight/polybag } \\
\qquad(\mathrm{g})\end{array}$ & Bulb number/polybag \\
\hline \multicolumn{5}{|l|}{ The factor I (Medium) } \\
\hline M1 = soil : paddy husk ash (1:1) & $2.47 \mathrm{a}$ & $3.01 \mathrm{a}$ & $79.20 \mathrm{a}$ & $8.08 \mathrm{a}$ \\
\hline M2 = soil : compost $(1: 1)$ & $2.40 \mathrm{a}$ & $2.85 \mathrm{a}$ & $74.94 \mathrm{a}$ & $7.05 \mathrm{a}$ \\
\hline \multicolumn{5}{|l|}{ The Factor II (Variety) } \\
\hline V1 (Agrihorti 1) & $2.61 \mathrm{a}$ & $2.53 \mathrm{a}$ & $68.56 \mathrm{a}$ & $7.9 \mathrm{a}$ \\
\hline V2 (Mentes) & $2.26 \mathrm{~b}$ & $3.34 \mathrm{a}$ & $84.30 \mathrm{a}$ & $7.37 \mathrm{a}$ \\
\hline
\end{tabular}

Means followed by the same letters in the same columns do not differ significantly as determined by HSD test at 0.05 probability level

Generally, this result indicated that the media showed good performance of the shallots yield (Figure 1). A good medium for vegetable crops is soil with a mixture of organic manures. The normally organic materials for media preparation were sawdust, sand or gravel, peat, perlite, vermiculite, cattle manure, and paddy husk ash (Suthamathy \& Seran, 2011). In addition to Yoldas, et al., (2011) found that organic manure enhanced shallot yield. Rice husk organic compounds were C (39.8-41.1\%), H
(5.7-6.1\%), $\mathrm{O} \quad(0.5-0.6 \%)$, and $\mathrm{N} \quad(37.4 \%-36.6 \%)$ (Korotkova, et al., 2016). Due to rice husk has high Nitrogen content, it could increased shallot yield (Hilman, et al., 2014). Kabir, et al., (2016) added that rice straw was an appropriate organic matter to the crop due to more efficient water conservation. Organic matter affected bulb diameter in shallots (Gadelrab \& Elamin, 2013).
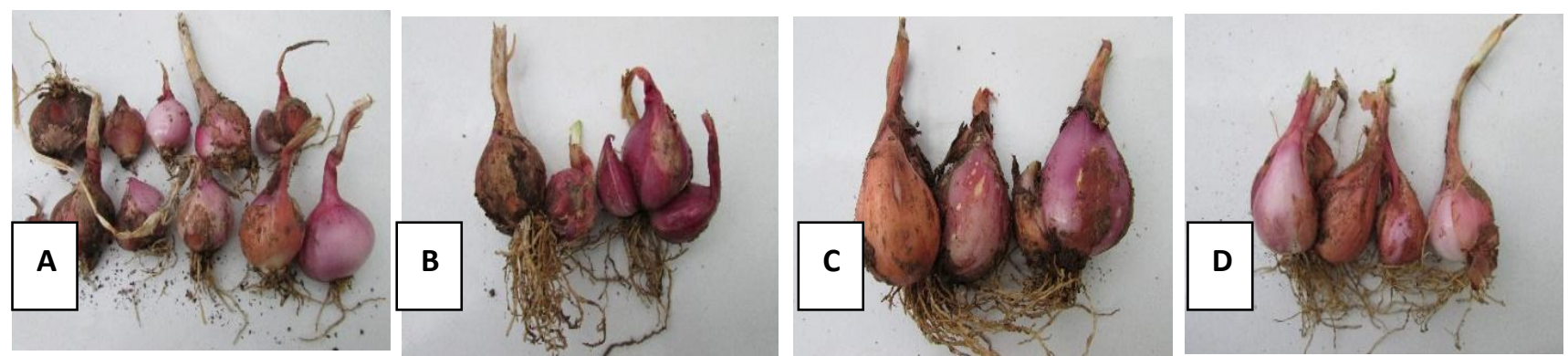

Figure 1. The appearance of two varieties in different medium (A. M1V1, B. M2V1, C. M1V2, D. M2V2) 
The result revealed that bulb weight on two varieties were 68.56 and 84.30 grams. The other experiment by Shimeles (2014) produced 58 to 60 grams of bulb weight on different varieties of shallot. The average bulb number per polybag on different variety was 7.37 to 7.9. It was an ideal number of the bulb because Woldetsadik (2003) stated that shallot plants produce bulb from 2 to 20 or more pieces. This result was similar to study by Aklilu \& Dessalenge (2015), in Ethiopia could produce a minimum 2.1 number of split bulb of shallot and a maximum 5.5 number of them. However, the bulb diameter on every variety, 2.26-2.61 cm, was not the ideal size for the market because the consumer requires bulb, which sizes $3-4 \mathrm{~cm}$ in diameter. There were significant differences in bulb diameter; however, there were no significant differences in bulb height, fresh bulb weight per polybag, and bulb number per polybag. Two cultivars, due to the varieties, had the same ability to utilize the nutrients. Tesfa, et al., (2015) informed that the differences of bulb yield between cultivars due to genetic variation and the ability to utilize nutrients.

\section{CONCLUSION}

Both media showed good performance on shallots yield because they produced high yield (fresh bulb weight per polybag), and these varieties were significant differences on bulb diameter; however they were not significant differences on bulb height, fresh bulb weight per polybag, and bulb number per polybag. Those media are precise media due to they contain organic materials.

\section{REFERENCES}

Adu-Yeboah, P., Amoah, F., Dwapanyin, A., Opoku-Ameyaw, K., Opoku-Agyeman, M., Acheampong, K., ... Owusu-Ansah, F. (2015). Effects of Polybag Size and Seedling Age at Transplanting on Field Establishment of Cashew (Anacardium occidentale) in Northern Ghana. American Journal of Experimental Agriculture, 7(5), 308-314. doi:10.9734/ajea/2015/16122

Aklilu, S., \& Dessalenge, L. (2015). The performance of true seed shallot lines under two methods of planting at different environments of Ethiopia. Research Journal of Agriculture and Environmental Management, 4(3), 174-179.

Anisyah, F., Sipayung, R., \& Hanum, C. (2014). Pertumbuhan dan produksi bawang merah dengan pemberian berbagai pupuk organik. Jurnal Agroekoteknologi, 2(2).

Ariyanti, N. A., Torikai, K., Kirana, R. P., Hirata, S., Sulistyaningsih, E., Ito, S. I., ... \& Shigyo, M. (2018). Comparative study on phytochemical variations in Japanese F1 varieties of bulb onions and south-east Asian shallot landraces. The Horticulture Journal, OKD-066.

C.A., P.-O., J.C., O., A. A., N., P.A., O., I.I., I., ... E.C, O. (2014). Efficacy of Five Different Growth Media on Seedling Emergence and Juvenile Phenology of Monodora myristica (African nutmeg, Ehuru) in the Nursery. IOSR Journal of Agriculture and Veterinary Science, 7(5), 60-63. doi:10.9790/238007516063
Fattorusso, E., Iorizzi, M., Lanzotti, V., \& Taglialatela-Scafati, O. (2002). Chemical composition of shallot (Allium ascalonicum Hort.). Journal of agricultural and food chemistry, 50(20), 5686-5690.

Gadelrab, H. M., \& Elamin, S. M. (2013). Effect of different organic fertilizers on growth, yield and total soluble solid of the onion (Allium cepa L.) variety Baftaim-s.

Getahun, D. (2016). Bulb placement effects on growth performance and yield of shallot (Allium cepa L. Aggregatum group). International Journal of Research Studies in Agricultural Sciences, 2, 33-38.

Hilman, Y., Sopha, G. A., \& Lukman, L. (2014). Nitrogen effect on production, nutrients uptake and nitrogen-use efficiency of shallot (Allium cepa var aggregatum). Advances in Agriculture \& Botanics, 6(2), 128-133.

Kabir, M. A., Rahim, M. A., \& Majumder, D. A. N. (2016). Productivity of garlic under different tillage methods and mulches in organic condition. Bangladesh Journal of Agricultural Research, 41(1), 53-66.

Kemal, Y. O. (2013). Effects of irrigation and nitrogen levels on bulb yield, nitrogen uptake and water use efficiency of shallot (Allium cepa var. ascalonicum Baker). African Journal of Agricultural Research, 8(37), 4637-4643.

Khater, E. S. G. (2015). Some Physical and Chemical Properties of Compost. International Journal of Waste Resources, 05(01). doi:10.4172/2252-5211.1000172

Korotkova, T. G., Ksandopulo, S. J., Donenko, A. P., Bushumov, S. A., \& Danilchenko, A. S. (2016). Physical properties and chemical composition of the rice husk and dust. Orient. J. Chem, 32(6), 3213-3219.

Liang, J.-Y., Hsu, A.-C., Lan, X.-Y., Chen, K.-Y., Chen, P.-S., Chou, W.-M., ... Yuann, J.-M. P. (2012). The Preparation of Preserved Shallot Powders and a Pilot Study of the Antioxidative Effect of Their Aqueous Extracts on the Formation of Hydroxyl Radical Species. Open Journal of Applied Sciences, 02(04), 209-215. doi:10.4236/ojapps. 2012.24031

Mahdalena, M. (2016). Respon Pertumbuhan dan Produksi Bawang Merah (Allium Ascalonicum L) terhadap Pengaruh Berbagai Media Tanam dan Pemberian Mikro Organisme Lokal (Mol) Keong Mas. Agrifor, 15(2), 233-248.

Moradi, Y., Sardareh, H. M., Ghasemi, H., Mohamadi, N., Moradi, M. N., \& Zijoud, S. H. (2013). Medicinal properties of persian shallot. European Journal of Experimental Biology, 3(1), 371-379.

Mohammadi-Motlagh, H.-R., Mostafaie, A., \& Mansouri, K. (2011). Anticancer and anti-inflammatory activities of shallot (Allium ascalonicum ) extract. Archives of Medical Science, 1, 38-44. doi:10.5114/aoms.2011.20602

Priyadharsini, P., Pandey, R., \& Muthukumar, T. (2012). Arbuscular mycorrhizal and dark septate fungal associations in shallot (Allium cepa L. var. aggregatum) under conventional agriculture. Acta Botanica Croatica, 71(1), 159-175. doi:10.2478/v10184-011-0058-1

Purba, R. (2014). Applications of NPK phonska and KCl fertilizer for the growth and yield of shallots (Allium ascalonicum) in Serang, Banten. International Journal of Applied, 4(3).

Santosa, M., Suryanto, A., \& Maghfoer, M. D. (2015). Application 
of biourine on growth and yield of shallot fertilized with inorganic and organic fertilizer in Batu, East Java. AGRIVITA Journal of Agricultural Science, 37(3), 290-295. doi:10.17503/agrivita-2015-37-3-p290-295

Shimeles, A. (2014). The performance of true seed shallot lines under different environments of Ethiopia. Journal of Agricultural Sciences, Belgrade, 59(2), 129-139.

Sulistyaningsih, E., Yamashita, K., \& Tashiro, Y. (2002). Genetic Characteristics of the Indonesian White Shallot. Engei Gakkai Zasshi, 71(4), 504-508. doi:10.2503/jjshs.71.504

Susanawati, S., Jamhari, J., \& Masyhuri, M. (2015). Price behavior and market integration of shallot in Java Indonesia. International Journal of Agriculture System, 3(2), 193-204.

Suthamathy, N., \& Seran, T. H. (2011). Growth and Yield Response of Red Onion (Allium ascalonicum L.) Grown in Different Potting. Journal of Phytology.

Tambunan, W. A., Sipayung, R., Sitepu, F. E. (2014). Pertumbuhan dan produksi bawang merah (Allium ascalonicum L.) dengan pemberian pupuk hayati pada berbagai media tanam. Jurnal Online Agroteknologi, 2(2), 825-836.

Tesfa, T., Woldetsadik, K., \& Bayu, W. (2014). Shallot Yield, Quality and Shelf-life as Affected by Nitrogen Fertilizer. International Journal of Vegetable Science, 21(5), 454-466. doi:10.1080/19315260.2014.895790

Woldetsadik, K. (2003). Shallot (Allium cepa var. ascolonicum) responses to plant nutrients and soil moisture in a sub-humid tropical climate. Doctoral dissertation, Swedish University of Agricultural Sciences).

Yitagesu-Kuma, A. N., \& Tigist Alemu, A. A. (2015). Onion Production for Income Generation in Small Scale Irrigation Users Agropastoral Households of Ethiopia. Journal of Horticulture, 02(03). doi:10.4172/2376-0354. 1000145

Yoldas, F., Ceylan, S., Mordogan, N., \& Esetlili, B. C. (2011). Effect of organic and inorganic fertilizers on yield and mineral content of onion (Allium cepa L.). African Journal of Biotechnology, 10(55), 114488-11482. 